\title{
PRELIMINARY INVESTIGATIONS UPON TWO CELLU. LOSIC WASTES AS SOURCES FOR XYLOSE
}

\author{
By W. L. Hall, C. S. Slater, and S. F. Acree
}

\section{ABSTRACT}

Technical methods to isolate and utilize the sugars, lignins, and celluloses in cellulosic wastes were begun with a preliminary investigation of peanut hulls and cottonseed-hull bran. The ash content of these materials was extensively studied and the ash was found to be bound in such a manner that with a mild chemical treatment it could be removed almost completely when the materials were subsequently washed with water. Cottonseed-hull bran proved to be an excellent source for the commercial production of the pentose sugar, xylose. An improved method to produce xylose was developed. The process is now being run experimentally on a semicommercial scale so as to obtain xylose in 100 -poundper-day batches.

\section{CONTENTS}

I. Introduction .

II. Investigations to determine suitable conditions for xylose production. 331

1. Moisture content ...

2. Ash content ..... 331

3. Xylose content... 334

(a) Peanut hulls

(b) Cottonseed-hull bran .................... 336

III. A modified process for the production of xylose from cottonseed-hull bran .

IV. Summary

\section{INTRODUCTION}

Cellulose waste products, such as oat hulls, corncobs, and stalks, peanut hulls, cotton burrs, and cottonseed hulls, straws and bagasse, all total annually many million tons. Although a small percentage of these materials is being utilized, the chemist and engineer have an intricate problem to solve before they develop markets and processes for the consumption of the enormous tonnage of such wastes.

The aim of the industrial chemist is to use all of his raw material and have no waste. But when straw or wood is converted into pulp or cellulose fiber, the sugar and lignin are burned to recover admixed chemicals or turned into a stream or cesspool. When hardwood is distilled, or softwood dry cooked with acids to produce fermentable sugars, the cellulose is rendered of no value as such. The ideal to be reached is then to subject the cellulosic wastes to a series of mild extractions to recover and use the products of hydrolysis, such as pectin and arabinose in the case of beet wastes ${ }^{1}$ from the sugar-beet industry, and xylose in the case of bagasse ${ }^{2}$ or other agricultural wastes. Gums, arabans, xylans, hemicelluloses, lignin bodies-and ash, in those cases where it has a fertilizing value-may also be extracted and used while leaving the plant fibers uninjured, freed of these encrusting or cementing and chemically bound materials, and, hence, more suit- 
able for the manufacture of crude fiber commodities or high-grade cellulose.

In this paper are set forth some of the preliminary analyses and work done on the hydrolysis of peanut hulls and cottonseed-hull bran, chiefly to devise methods for production of xylose and xylose molasses without materially injuring the plant fiber for use by the cellulose technologist: These raw materials are available in tonnage lots at central plants. It has been estimated that the peanut industry could readily collect annually 50,000 tons of hulls, and the cottonseed-oil plants can furnish yearly over $1,000,000$ tons of cottonseed-hull bran. This bran is obtained as follows:

The cottonseed is mechanically denuded of its useful, adhering fuzz, then broken, and its valuable kernel is removed; or the cottonseed may first be broken, when the kernel and next the fuzz are removed; in either case there is left a fairly clean hull. It is this hull which, when ground, is known as cottonseed-hull bran and has proved to be an excellent source for xylose.

Xylose is a pentose, a 5-carbon aldose sugar $\left(\mathrm{C}_{5} \mathrm{H}_{10} \mathrm{O}_{5}\right)$ discovered by Koch $(1886)^{3}$ and further studied by others. ${ }^{4}$ It has a wide distribution in many plants. Such agricultural waste products as cottonseed-hull bran, peanut hulls, cornstalks and cobs, cereal straws and hulls, bagasse, etc., are relatively fertile sources for xylose. Woods, and especially hardwoods, contain appreciable quantities; in fact, because it was first obtained from these products it was given the name of "wood sugar."

This sugar is so important as a constituent of plants that all routine analyses include it along with the crude fiber, protein, fats, and ash. It is safe to say that many thousands of analyses have been made for the xylose $\left(\mathrm{C}_{5} \mathrm{H}_{10} \mathrm{O}_{5}\right)$ or pentosan $\left(\mathrm{C}_{5} \mathrm{H}_{8} \mathrm{O}_{4}\right)_{\mathrm{n}}$ contents of industrial vegetable materials. However, with all this interest in pentosans of which xylose is probably the chief constituent, no simple methods have been developed heretofore for its commercial production and utilization. That goal is the object of our investigations. Xylose is not known to occur in the free state as does sucrose in beets, cane, and fruits. It is found sometimes as a constituent of gums or starchy materials which can be separated from the cellulose fiber and, perhaps, is also present as an integral part of the cellulose itself. The literature on the chemistry of xylose and its occurrence is quite extensive, a discussion of which is beyond the scope of this paper. From a careful study of the same, however, one may conclude that the xylose molecules must be attached through the aldehyde or alcohol groups or both to a number of different constituents with varying degrees of stability or resistance to hydrolytic separation. With this idea in mind, it has been the aim to liberate or produce the xylose molecule through a combination of physical and chemical treatments and in such quantities as to make xylose a commercial product.

That peanut hulls and cottonseed-hull bran yield xylose on acid hydrolysis is not new to science, but little has been accomplished in the direction of commercial utilization of such wastes. Neither has a detailed study been made as to the best and simplest methods to produce xylose in quantities large enough to open up avenues for its commercial utilization.

8 Pharm. Zeit. f. Russland 25, p. 619; 1886.

- Sugar, 25, p. 124; 1923, gives a good bibliography and discussion. 


\section{INVESTIGATIONS TO DETERMINE SUITABLE CONDI- TIONS FOR XYLOSE PRODUCTION}

\section{MOISTURE CONTENT}

The percentage of moisture in air-dried cellulosic materials varies with the temperature and humidity of the surrounding atmosphere. It is important to determine this moisture content in order to know the actual weight of dry substance bought and used in manufacturing processes and the percentage yields obtained. It is also important to know the moisture content in the analysis of cellulosic materials in order to evaluate correctly the other constituents. Results of analyses are often given on the original air-dried material and on the "bone-dry" or "oven-dried" substance supposed to be free of absorbed water.

The moisture content of peanut hulls as recorded in the literature $^{567}$, varies with samples. Those samples used in this investigation also gave varying values according to the methods used in the determination.

TABLE 1.-Moisture content of peanut hulls and cottonseed-hull bran

\begin{tabular}{|c|c|c|c|}
\hline Material & $\begin{array}{l}\text { Dried } 10 \\
\text { days at } \\
105^{\circ} \mathrm{C} .\end{array}$ & $\begin{array}{l}\text { Toluene } \\
\text { method } 1\end{array}$ & $\begin{array}{l}\text { Vacuum } \\
\text { desicca- } \\
\text { tion over } \\
\mathrm{H}_{2} \mathrm{SO}_{4}\end{array}$ \\
\hline $\begin{array}{l}\text { Commercial hulls } \\
\text { Commercial ground hulls.................. } \\
\text { Specially ground air-blown hulls... } \\
\text { Cottonseed-hull bran }\end{array}$ & $\begin{array}{r}\text { Per cent } \\
8.6 \\
8.5\end{array}$ & $\begin{array}{r}\text { Per cent } \\
9.0 \\
7.6 \\
4.0 \\
11.8\end{array}$ & $\begin{array}{r}\text { Per cent } \\
27.5 \\
6.3 \\
4.5 \\
312.25\end{array}$ \\
\hline
\end{tabular}

1 Values were obtained by boiling $100 \mathrm{~g}$ samples of the hulls with water-saturated toluene and measuring the volume of water condensed with the toluene in an apparatus similar to the usual water-determination apparatus.

${ }^{2}$ Reed (see footnote 6 , below) found an average of 7.9 per cent.

3 Markley, J. Am. Soc. Agron., 20, p. 1103; 1928.

\section{ASH CONTENT}

All who have had experience in the production and crystallization of sugars know the advantages of dealing with sirups or extracts low in ash content. Ash present in appreciable quantities materially interferes with the crystallization of sugars. Since the waste agricultural products studied show relatively high total ash contents, a detailed study of the total bound and removable ash was made. It was found that the total ash was largely made up of two components, namely, adhering dirt and an absorbed or chemically bound ash.

Commercial peanut hulls averaging 5.0 per cent total ash were separated into three fractions by mechanically agitated sieves: First, the fraction which would pass through a No. 20 sieve; second, the fraction which was retained by a No. 20 sieve, but would pass through a No. 8 sieve; and third, the fraction that was retained by a No. 8 sieve. The ash content of each fraction was determined and also the relative distribution of the hulls of these particular sizes. The results are tabulated in Table 2.

7 U. S. Dept. Agr. Bull. No. 1096, p. 6; 1922. 
TABLE 2.-Mechanical removal of extraneous ash (dirt) from $100 \mathrm{~g}$ samples of peanut hulls by sieving or air blasting

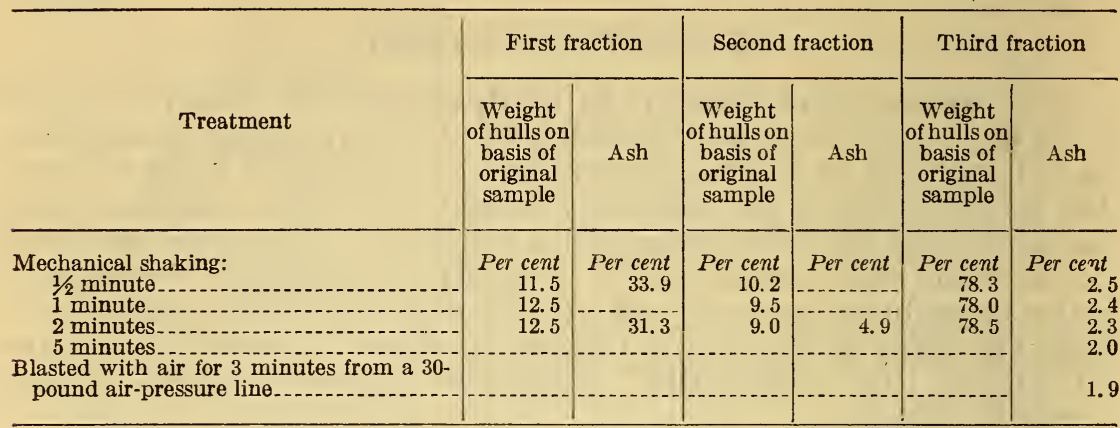

Most of the ash was separated with that fraction which passed through the No. 20 sieve. Over 30 per cent of that fraction was ash. The hulls retained by the No. 8 sieve contained only 2.0 to 2.5 per cent ash. Vigorous air blowing of a sample in a No. 8 sieve also removed the adhering dirt so that the sample contained less than 2.0 per cent of ash. The residual or bound ash in hulls of the third fraction resisted leaching with hot water. An acid extraction of the dirt-free hulls removed this remaining ash down to 0.15 to 0.4 per cent and left a very pure organic fiber for the manufacture of xylose and cellulose.

The nature of this residual or bound ash is of both theoretical and practical importance. It may consist of phosphates, silicates, etc., insoluble in water but soluble in acids, or of metallic cations like potassium, sodium, calcium, etc., combined with fairly strong acid groups making up the complex cellulosic matter, or of both types. When the cleaned hulls were burned, the ash residue was decidedly alkaline to usual indicators. It was titrated with acid, using bromcresol green indicator, and as the end points developed slowly, the mixture was allowed to stand between additions of acid. Warming and then cooling the sample during the titration accelerated the procedure. The titration value indicated that the ash was largely a carbonate instead of a phosphate, silicate, etc. Those papers in the literature that deal with detailed analyses of the ash content of peanut hulls ${ }^{8}$ are in agreement with the data showing large amounts of basic constituents especially potash in comparison with the acid constituents, such as phosphates, etc.

If the greater part of the potash present were combined with acidlike groups of the plant material, or absorbed thereupon, potassium carbonate should be formed by ashing, and was actually found. Furthermore, combined ash of such a nature, upon treatment with mineral acids, would form the inorganic salt of the mineral acid which could then be washed out.

In this leaching with the dilute mineral acid, the alkali-combining power of the peanut hull, or possibly the carboxyl content, was not appreciably altered in the majority of cases; for additional treatments

8 See footnotes 5,6 , and 7, p. 331 . 
of the ash-free hulls with alkali, and subsequent washing, produced hulls having again a high ash content which in turn could again be removed by the acid treatment, but not with hot water. The failure of hot water to remove the alkali metal shows that it was not present as the easily hydrolyzed salt of a lignin phenolic group, but possibly as the salt of a carboxylic or stronger acid.

In harmony with this idea is the fact that such relatively ash-free hulls when finely ground may be titrated rapidly, at first, against alkali and phenolphthalein. Cleaned hulls treated with an excess of sodium hydroxide were washed until neutral, dried, and ashed; nearly pure sodium carbonate was formed as shown by analysis. ${ }^{9}$

The following table presents experimental evidence that such an ash-combining power was present.

TABLE 3.-Effect of hydrolysis on the ash content of peanut hulls. Hull residues oven dried at $105^{\circ} \mathrm{C}$.

\begin{tabular}{|c|c|c|c|}
\hline Character of hulls & Treatment & $\begin{array}{c}\text { Ash re- } \\
\text { maining } \\
\text { in thor- } \\
\text { oughly } \\
\text { washed } \\
\text { hulls }\end{array}$ & $\begin{array}{c}\text { Titration } \\
\text { of ash } \\
\text { ml 1.0 } \\
N \mathrm{H}_{2} \mathrm{SO}_{4} \\
\text { per gram } \\
\text { of ash }\end{array}$ \\
\hline Commercial hulls_.- & None & Per cent & \\
\hline Do.................. & Mechanically cleaned, air blown. & $\begin{array}{l}10.0 \\
11.9\end{array}$ & 11.3 \\
\hline Commercial hulls mechanically cleaned.. & $0.18 \mathrm{~N} \mathrm{NaOH}$ for 1 hour at $100^{\circ} \mathrm{C}$ & 2.0 & 14. \\
\hline Do & $0.50 \mathrm{~N} \mathrm{NaOH}$ for 1 hour at $100^{\circ} \mathrm{C}$ & 2.3 & 17. \\
\hline (n) & $0.16 \mathrm{NHNO}_{3}$ for $11 / 4$ hours at $100^{\circ} \mathrm{C}$ & .18 & -5 \\
\hline Commercial hulls mechanically cleaned. & $0.25 \mathrm{~N} \mathrm{NaOH}$ two separate hydrolyses & 1.7 & 17. \\
\hline $\begin{array}{l}\text { Commercial hulls mechanically cleaned, } \\
\text { hydrolyzed } 11 / 2 \text { hours at } 100^{\circ} \mathrm{C} \text {. (twice) } \\
\text { with } 0.25 \mathrm{~N} \mathrm{NaOH} \text {. }\end{array}$ & $0.32 \mathrm{~N} \mathrm{HNO}_{3} 1$ hour at $100^{\circ} \mathrm{C}$ & .16 & 2 \\
\hline Commercial hulls mechanically cleaned.-. & $0.32 \mathrm{NHNO} \mathrm{HN}_{3} 2$ hours & .18 & \\
\hline $\begin{array}{l}\text { Commercial hulls mechanically cleaned, } \\
\text { hydrolyzed } 2 \text { hours at } 100^{\circ} \mathrm{C} \text {. with } 0.32 \\
N \mathrm{HOO}_{3} \text {. }\end{array}$ & $0.25 \mathrm{~N} \mathrm{NaOH} 1$ hour at $100^{\circ} \mathrm{C}$ & 3.04 & 18. \\
\hline Commercial hulls (uncleaned). & $0.11 \mathrm{NHNO}_{3}$ old battery hydrolysates & 3.08 & \\
\hline $\begin{array}{l}\text { Commercial hulls (uncleaned) extracted } \\
\text { in battery with } 0.11 \mathrm{~N} \mathrm{HNO}_{3} \text {. }\end{array}$ & $\begin{array}{l}\text { 1.0 } \mathrm{N} \mathrm{NaOH} 11 / 2 \text { hours; } 10 \text { pounds steam } \\
\text { pressure. }\end{array}$ & 3.53 & \\
\hline
\end{tabular}

1 Hulls not washed.

2 The high ash was due to the presence of an accumulation of inorganic materials in the battery hydrolysates which were run at 10 pounds steam pressure in a regular battery process described later in this paper.

Similar experiments with cottonseed-hull bran lead to the same conclusions regarding the acid groups and ash, as shown in Table 4. Naturally, cottonseed hulls have less chance than peanut hulls to contain adhered dirt.

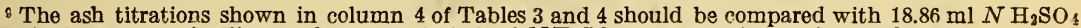
required per gram of sodium carbonate and $14.50 \mathrm{ml} N \mathrm{H}_{2} \mathrm{SO}_{4}$ per gram of potassium carbonate. 
TABLE 4.-Effect of hydrolysis on the ash content of cottonseed-hull bran. Bran residues oven dried at $105^{\circ} \mathrm{C}$.

\begin{tabular}{|c|c|c|c|}
\hline Charscter of bran & Hydrolysis treatment & $\begin{array}{l}\text { Ash re- } \\
\text { maining } \\
\text { in thor- } \\
\text { oughly } \\
\text { washed } \\
\text { bran }\end{array}$ & $\begin{array}{l}\text { Titration } \\
\text { ml } 1.0 \\
\mathrm{NH}_{2} \mathrm{SO}_{4} \\
\text { per gram } \\
\text { of ash }\end{array}$ \\
\hline Commercial cottonseed-hull bran. & None & $\begin{array}{c}\text { Per cent } \\
12.3\end{array}$ & \\
\hline Do & $\begin{array}{l}\text { Distilled water7 hours on the steam bath- } \\
\text { Completely covered with } 0.16 N \text { HNO }\end{array}$ & $\begin{array}{l}1.8 \\
.54\end{array}$ & 15. 5 \\
\hline Do.- & $\begin{array}{l}\text { at room temperature for } 24 \text { hours. } \\
\text { Completely covered with } 0.16 \mathrm{~N} \mathrm{H}_{2} \mathrm{SO}_{4} \\
\text { at room temperature for } 24 \text { hours. }\end{array}$ & .47 & \\
\hline $\begin{array}{l}\text { Dommercial cottonseed-hull bran hydro- } \\
\text { lyzed once, } 1 \text { hour with } 0.11 \mathrm{HCl} \text { at }\end{array}$ & $0.11 \mathrm{~N} \mathrm{HCl}$ for 1 hour at $100^{\circ} \mathrm{C}$ & $\begin{array}{l}.46 \\
.46\end{array}$ & $\begin{array}{r}11.0 \\
3.9\end{array}$ \\
\hline $\begin{array}{l}\text { Commercial cottonseed-hull bran hydro- } \\
\text { lyzed twice, } 1 \text { hour each with } 0.11 \mathrm{~N} \mathrm{HCl} \\
\text { at } 100^{\circ} \mathrm{C} \text {. }\end{array}$ & $0.26 \mathrm{NHCl}$ for $11 / 2$ hours at $100^{\circ} \mathrm{C}$. & .46 & .21 \\
\hline Commercial cottonseed-hull bran. & $0.26 \mathrm{~N} \mathrm{HCl}$ for $1 \frac{1}{2}$ hours at $25^{\circ} \mathrm{C}$ & .20 & $<0.1$ \\
\hline Do_.- & $0.26 \mathrm{~N}$ HCl for 3 hours at $25^{\circ} \mathrm{C}$ & .20 & $\begin{array}{r}.7 \\
1.8\end{array}$ \\
\hline Do. & $\begin{array}{l}0.26 \mathrm{~N} \text { HCl } 2 \text { separate hydrolyses } 1 \text { hour } \\
\text { each at } 100 \mathrm{C} \text {. }\end{array}$ & .12 & 3.5 \\
\hline $\begin{array}{l}\text { Commercial cottonseed-hull bran hydro- } \\
\text { lyzed twice with } 0.11 \mathrm{NHCl} \text { at } 100^{\circ} \mathrm{C} \text {. }\end{array}$ & $\begin{array}{l}0.12 \mathrm{~N} \mathrm{HNO} \mathrm{H}_{3} \text { for } 1 \text { hour at } 100^{\circ} \mathrm{C} \\
0.17 \mathrm{~N} \mathrm{NaOH} \text { for } 1 \text { hour at } 100^{\circ} \mathrm{C}\end{array}$ & 2.52 & $\begin{array}{l}10 \\
17\end{array}$ \\
\hline Commercial cottonseed-hull bran & & 2.6 & 13 \\
\hline $\begin{array}{l}\text { Commercial cottonseed-hull bran hydro- } \\
\text { lyzed once } 0.26 \mathrm{~N} \mathrm{HCl} \text { at } 100^{\circ} \mathrm{C} \text {. }\end{array}$ & $\begin{array}{l}0.17 \mathrm{~N} \mathrm{NaOH}_{2}^{2} \text { separate hydrolyses } 1 \\
\text { hour each at } 100^{\circ} \mathrm{C} \text {. }\end{array}$ & 2.8 & 16 \\
\hline
\end{tabular}

1 Bran not washed.

\section{XYLOSE CONTENT}

In the production of xylose from agricultural wastes, one is handicapped by the lack of simple, precise analytical methods for its exact estimation. It has long been known that pentoses, upon distillation in a 12 per cent hydrochloric acid solution, are converted almost quantitatively into furfural. ${ }^{10}$ The resulting furfural which is contained in the distillate can be determined gravimetrically with phloroglucine ${ }^{11}$ or thiobarbituric acid ${ }^{12}$ or volumetrically. ${ }^{13}$ Waste materials containing xylose, and xylose extracts from the same, may also contain other organic compounds - that is, arabinose, glucuronic acid, etc.-in lesser quantities, which likewise yield furfural upon distillation with 12 per cent hydrochloric acid. Difficulties were encountered in quantitative furfural determinations if the acid distillation was made upon material containing nitric acid or nitrates. Calculations of xylose yields and xylose contents, based upon furfural determinations, are only approximate and indicative. ${ }^{14}$

\section{(a) PEANUT HULLS}

The nature of the work so far on peanut hulls has been only preliminary. Hydrolyses were made upon commercial peanut hulls with the hope of determining the amount of pentoses present and the easiest methods of extracting such from the hulls to produce the

10 Official and Tentative Methods of Analysis. 2d Edition, 1925. Association of Official Agricultural Chemists, Box 290, Pennsylvania Avenue post office, Washington, D. C

11 See footnote 10

12 Dox and Plaisance, J. Am. Chem. Soc., 38, p. 2156; 1916.

13 Pervier and Gortner, J. Ind. Eng. Chem., 15, pp. 1167 and 1255; 1923.

14 The method of Dox and Plaisance (footnote 12) was used exclusively for furfural determinations. The furfural value times the factor, $\frac{\mathrm{C}_{8} \mathrm{H}_{10} \mathrm{O}_{5}}{\mathrm{C}_{6} \mathrm{H}_{8} \mathrm{O}_{4}}=1.563$, was used for pentose or xylose equivalent in all such calculations in this paper. 
sugars, chiefly xylose. Furfural determinations were made upon untreated peanut hulls, and the calculated furfural yields were compared with those obtained from hull residues after they had been hydrolyzed in various ways. This comparison gave an insight into the efficacy of the hydrolysis treatment in removing furfural-yielding compounds.

TABLE 5.-Furfural yields of unhydrolyzed and hydrolyzed peanut hulls

\begin{tabular}{|c|c|c|c|}
\hline Sample & Treatment & $\begin{array}{c}\text { Furfural } \\
\text { yield } \\
\text { oven- } \\
\text { dried } \\
\text { basis }\end{array}$ & $\begin{array}{c}\text { Pentose } \\
\text { equiva- } \\
\text { lent based } \\
\text { on fur- } \\
\text { fural } \\
\text { deter- } \\
\text { mination }\end{array}$ \\
\hline & & Per cent & Per cent \\
\hline Commercial hulls & None.................... & 10.9 & 17.0 \\
\hline Do......... & Commercially ground & 10.8 & 16.9 \\
\hline & Mechanically cleaned, then finely ground & 13.0 & 20.3 \\
\hline 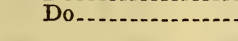 & $\begin{array}{l}\text { Hulls hydrolyzed } 1 \text { hour at } 100^{\circ} \mathrm{C} \text {. with } 2 \text { per } c \text {. cent } \mathrm{NaOH} \text {, } \\
\text { washed and analyzed. }\end{array}$ & $11 . \mathrm{i}$ & 17.3 \\
\hline Do_ & Hulls hydrolyzed with $0.15 \mathrm{~N} \mathrm{HNO}_{3}$ in a battery run, & 6.5 & 10.1 \\
\hline Do & Hulls hydrolyzed with $0.2 \mathrm{NH}_{2} \mathrm{SO}_{4}$ in a battery run, washed & 5.1 & 7.9 \\
\hline $\begin{array}{l}\text { Commercially ground } \\
\text { hulls. }\end{array}$ & $\begin{array}{l}\text { Hulls }{ }^{1} \text { hydrolyzed with cold } 42 \text { per cent } \mathrm{HCl} \text {, washed and } \\
\text { analyzed. }\end{array}$ & $<1.0$ & $<1.5$ \\
\hline
\end{tabular}

1 Such an acid treatment disintegrated and charred the hulls, leaving them worthless for further use as cellulose sources.

Table 5 gives a few representative analyses showing that peanut hulls may contain from 17 to 20 per cent of furfural-yielding materials, the major portion of which must have been derived from pentoses. The yields of furfural from these hydrolyzed hulls were materially diminished by the hydrolyses. This fact indicated that pentoses were being removed from the fiber mass.

A very concentrated acid, like 42 per cent hydrochloric acid, removed almost completely in the cold the furfural-yielding materials.

A battery cycle method of three successive hydrolyses was then started to obtain sugar on a small scale by a method similar to commercial battery extractions. In this system the fresh hulls were extracted with the concentrated sugar solution containing the hydrolytic agent, while the final treatment, for twice extracted hulls, was with the most dilute sugar solution containing the hydrolytic agent. These steps were continued in the conventional cycle until the hulls were finally washed with water to recover adhering materials, then removed from the cell for other uses, such as production of cellulose fibers. This cell was then filled with fresh hulls for the next cycle, etc.

Table 6 gives data on different batteries, Nos. 18 to 65 , which are sufficiently representative of these runs. In these and subsequent cases the Brix readings (per cent solids by weight for sucrose solutions) are used only in an indicative sense for possible concentrations of xylose. As the hulls used for these runs were neither physically nor chemically cleaned, the dissolved ash was one source of error in these readings. 
TABLE 6.-Battery extractions of peanut hulls

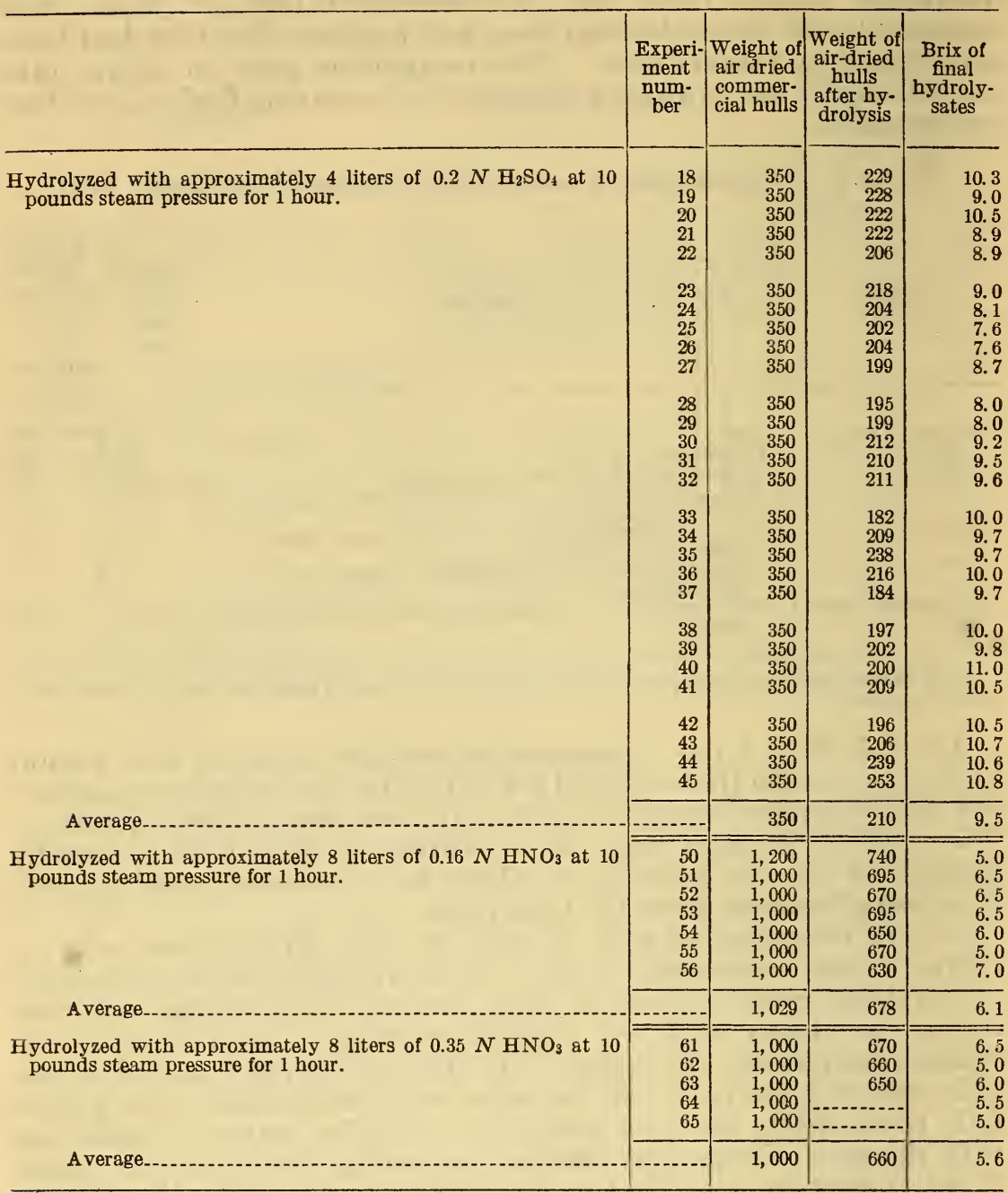

It is to be noted that in the case of nitric acid a doubling of the acid strength had little effect upon the concentration of the extract, also that sulphuric acid gave proportionally higher concentrations. Just whether the increment was due to increased sugar yields will require a more detailed study. The residual hulls were generally light in color and had lost by extraction about 34 to 40 per cent of their weight. The extracts showed by titration a small amount of organic acids. Attempts to isolate crystalline xylose from these hydrolysates were rather discouraging and require further study.

\section{(b) COTTONSEED-HULL BRAN}

Our investigations upon cottonseed-hull bran have been more extensive, since the bran has greater possibilities as a source for 
xylose. The researches of Euler, ${ }^{15}$ Hudson and Harding, ${ }^{16}$ Sherrard and Blanco, ${ }^{17}$ and just recently Markley ${ }^{18}$ in this laboratory, furnish fundamental and valuable information in this field. Markley found that such bran contained sufficient xylanlike bodies to give 22.29 per cent of its air-dried weight as furfural when distilled with 12 per cent hydrochloric acid, and that a 22.2 per cent furfural yield corresponded to 43.2 per cent pentose on the basis of Kröber's formulæ. ${ }^{19}$ Just what was the complete source of the furfural is not definitely known. However, other experiments indicated that the greater part came from pentosans. A series of hydrolysis experiments were made upon the bran in order to ascertain the most favorable conditions for hydrolysis. The results are tabulated in Tables 7 and 8.

TABLE 7.-Hydrolysis of cottonseed-hull bran with dilute hydrochloric acid-100 $\mathrm{g}$ samples treated with $300 \mathrm{ml}$ of acid

\begin{tabular}{|c|c|c|c|c|c|c|}
\hline $\begin{array}{l}\text { Experi- } \\
\text { ment } \\
\text { No. }\end{array}$ & Character of bran & Hydrolysis treatment & $\begin{array}{c}\text { Furfural } \\
\text { determi- } \\
\text { nation on } \\
\text { hydroly- } \\
\text { sate-per- } \\
\text { centage } \\
\text { on basis of } \\
\text { original } \\
\text { weight } \\
\text { of bran }\end{array}$ & $\begin{array}{l}\text { Pentose } \\
\text { equiva- } \\
\text { lent }\end{array}$ & $\begin{array}{l}\text { Furfural } \\
\text { determi- } \\
\text { nation } \\
\text { on bran } \\
\text { after hy- } \\
\text { drolysis- } \\
\text { bran } \\
\text { washed } \\
\text { dried at } \\
100^{\circ} \mathrm{C} \text {. }\end{array}$ & $\begin{array}{l}\text { Pentose } \\
\text { equiva- } \\
\text { lent }\end{array}$ \\
\hline & $\begin{array}{l}\text { Commercial cottonseed- } \\
\text { hull bran. }\end{array}$ & $\begin{array}{l}0.26 \mathrm{~N} \text { acid, } 11 / 2 \text { hours at } \\
25^{\circ} \mathrm{C} \text {. } \\
0.26 \mathrm{~N} \text { acid, } 3 \text { hours at } \\
25^{\circ} \mathrm{C} \text {. } \\
0.11 \mathrm{~N} \text { acid, } 1 \text { hour at }\end{array}$ & $\begin{array}{c}\text { Per cent } \\
<1.0 \\
<1.0 \\
1.96\end{array}$ & $\begin{array}{c}\text { Per cent } \\
<1.0 \\
<1.0 \\
3.05\end{array}$ & $\begin{array}{r}\text { Per cent } \\
25.3 \\
\\
25.3\end{array}$ & $\begin{array}{r}\text { Per cent } \\
39.5 \\
39.5\end{array}$ \\
\hline 4 & $\begin{array}{l}\text { Bran from experiment No. } \\
3 \text { thoroughly washed. } \\
\text { Bran from experiment No. }\end{array}$ & $\begin{array}{l}0.11 \mathrm{~N} \text { acid, } 1 \text { hour at } \\
100^{\circ} \mathrm{C} \text {. } \\
0.26 \mathrm{~N} \text { acid, } 1 \frac{1}{2} \text { hours at }\end{array}$ & $\begin{array}{l}5.77 \\
8.18\end{array}$ & $\begin{array}{l}9.02 \\
12.8\end{array}$ & $\begin{array}{r}18.5 \\
10.7\end{array}$ & $\begin{array}{r}28.9 \\
16.7\end{array}$ \\
\hline & $\begin{array}{l}4 \text { thoroughly washed. } \\
\text { Commercial cottonseod- } \\
\text { hull bran. }\end{array}$ & $\begin{array}{l}100^{\circ} \mathrm{C} . \\
0.26 \mathrm{~N} \text { acid, } 11 / 2 \text { hours at } \\
100^{\circ} \mathrm{C} \text {. }\end{array}$ & 14.8 & 23.3 & 12.1 & 18.9 \\
\hline
\end{tabular}

That cold dilute acid does not split off appreciable amounts of xylose or furfural-yielding compounds was quite interesting. When a given lot of bran was hydrolyzed by successive treatments with hydrochloric acid at $100^{\circ} \mathrm{C}$., the furfural or xylose yield was successively increased in a step-wise manner. The sum of the furfural so obtained plus that which the treated bran yielded on analysis was in fair agreement with the amount originally determined.

The function of time in relation to the amount of sugar produced by hydrolysis of the bran with 2.5 per cent $(0.7 N)$ hydrochloric acid was studied. Individual $8 \mathrm{~g}$ samples were refluxed on an electric hot plate with $400 \mathrm{ml}$ of acid for definite time intervals, ranging from 5 minutes to 2.5 hours. The aldose sugars produced during each interval were determined by an iodine and alkali titration procedure that is being developed in conjunction with this problem. The results are given in Table 8.

16 Euler, H., Grundlagen und Ergebnisse der Pflanzenchemie I, Braunschweig, p. 44; 1908.

$16 \mathrm{~J}$. Am. Chem. Soc., 39, p. 1038; 1917.

17 J. Ind. Eng. Chem., 12, p. 1160; 1920.

is See footnote 3 to Table 1, p. 331 .

io See footnote 10, p. 334 . 
TABLE 8.-Hydrolysis of cottonseed-hull bran (air dried) with 2.5 per cent hydrochloric acid at $100^{\circ} \mathrm{C}$.

\begin{tabular}{|c|c|c|c|c|c|c|c|c|c|c|}
\hline & \multicolumn{10}{|c|}{ Time (in minutes) } \\
\hline & 5 & 10 & 15 & 20 & 25 & 30 & 60 & 90 & 120 & 150 \\
\hline $\begin{array}{l}\text { Per cent rylose equivalent in hydro- } \\
\text { lysate, on basis of bran used-iodine } \\
\text { titration }\end{array}$ & 19.8 & 27.0 & 27.9 & 29.9 & 31.0 & 36.9 & 37.6 & 37.3 & 36.5 & 36.8 \\
\hline $\begin{array}{l}\text { Per cent xylose equivalent in hydro- } \\
\text { lysate, on basis of bran used-alkali } \\
\text { titration }\end{array}$ & 18.2 & 24.5 & 25.9 & 27.9 & 29.1 & 34.5 & 35.7 & 35.0 & 34.3 & 35.0 \\
\hline
\end{tabular}

It is seen from Table 8 that about one-half of the total sugar was formed in the first five minutes, and thereafter the percentage mounts gradually to a maximum in one hour. This maximum value, 37.6 per cent xylose, approximates the calculated pentose content, based on total furfural determinations given in Table 8, and when corrected for bran moisture gives the equivalent xylose yield on the basis of oven-dried bran; namely, 42.7 per cent. Markley ${ }^{20}$ found that cottonseed-hull bran yielded, on an oven-dried basis, under a similar treatment an equivalent of 43.5 per cent xylose. He based his value for xylose upon a copper value for reducing sugars but made only a final determination after hydrolysis for 2.5 hours.

Experiments were next made upon larger quantities of bran. The bran, 2,000 g, was given a preliminary acid wash with enough $0.16 \mathrm{~N}$ cold nitric acid to cover it completely. Between 4 and 5 liters were required. After soaking for 15 hours the bran was drained and washed, then treated with sufficient dilute acid to make the total volume of acid present about 6 liters of the desired normality. The batch was then first heated for one-half hour by escaping steam in an autoclave to $80^{\circ} \mathrm{C}$. and finally cooked at 10 pounds steam pressure. Results are given in Table 9.

TABLE 9.-Pressure hydrolysis of cleaned cottonseed-hull bran

\begin{tabular}{|c|c|c|c|}
\hline $2,000 \mathrm{~g}$ bran hydrolyzed with 6 liters acid at 10 pounds steam pressure & Brix & $\begin{array}{c}\text { Sugar in } \\
\text { hydroly- } \\
\text { sate de- } \\
\text { termined } \\
\text { by titra- } \\
\text { tion with } \\
\text { iodine and } \\
\text { alkali }\end{array}$ & $\begin{array}{l}\text { Sugar } \\
\text { yield, } \\
\text { on } \\
\text { basis } \\
\text { of bran } \\
\text { used }\end{array}$ \\
\hline $\begin{array}{l}0.16 N \mathrm{HNO}_{3} \text { for } 1 \text { hour } \\
0.16 \mathrm{~N} \mathrm{H}_{3} \mathrm{NO}_{3} \text { for } 2 \text { hours } \\
0.08 \mathrm{~N} \mathrm{H}_{2} \mathrm{SO}_{4} \text { for } 2 \text { hours } \\
0.16 \mathrm{~N} \mathrm{H}_{2} \mathrm{SO}_{4} \text { for } 2 \text { hours } \\
0.32 \mathrm{~N} \mathrm{H}_{2} \mathrm{SO}_{4} \text { for } 2 \text { hours }\end{array}$ & $\begin{array}{r}7.0 \\
11.5 \\
5.9 \\
10.0 \\
9.0\end{array}$ & $\begin{array}{r}\text { Per cent } \\
-8.8 \\
6.0\end{array}$ & $\begin{array}{r}\text { Per cent } \\
-26 \\
20 \\
21\end{array}$ \\
\hline
\end{tabular}

By way of comparison a batch of bran $(2,000 \mathrm{~g})$ was hydrolyzed as above with $0.16 N$ nitric acid, except that the preliminary ash treatment was omitted. A Brix reading of 9.0 resulted, yet the sugar content was only 2 per cent. Here the greater part of the hydrolyzing acid was neutralized by the alkali salts in the bran, and, consequently,

${ }^{20}$ See footnote 3 to Table 1, p. 331. 
was not available for hydrolytic activity. However, when the extract, which was quite colloidal and gummy, was further fortified with nitric acid to $0.16 \mathrm{~N}$ and again pressure cooked, the sugar content increased to 6.5 per cent. This evidence bears out the well-known fact that xylans are easily split off by dilute acids under pressure and that a higher concentration of acid is necessary to complete the hydrolysis. This experiment and those recorded in the table above bring out clearly that insufficient acid concentration and too short hydrolytic periods are to be avoided, and there is no advantage in doubling the concentration of the acid $(0.32 N)$. Longer cooking periods were also found to be unnecessary. In all pressure cooks the odor of furfural was quite noticeable, and especially so for the higher acid concentrations. The probability of the furfural being produced from xylose would be greater for the more concentrated acid cooks. Here, again, is another factor favoring hydrolysis with weak acid.

The bran residue (0.16 $\mathrm{N} \mathrm{H}_{2} \mathrm{SO}_{4}$, two-hour cook, Table 9) was thoroughly washed and rehydrolyzed as before with $0.16 \mathrm{~N}$ sulphuric acid. The second hydrolysate had a Brix of only 0.5 , showing that the first hydrolysis was sufficient. In contrast to this, the bran residue (0.08 $N \mathrm{H}_{2} \mathrm{SO}_{4}$, two-hour cook, Table 9) when similarly treated with $0.16 \mathrm{~N}$ sulphuric acid, gave a Brix reading of 3.7, showing that the first hydrolysis in this case was insufficient. These brans were again so hydrolyzed for the third time, producing small Brix values, 1.3 and 1.6 , respectively.

Such a process for the complete removal of sugar, even if only one cook were made, would accumulate, on a commercial scale, large volumes of weak sugar solutions. The battery method of three successive hydrolyses was next studied, whereby concentrated extracts were obtained. A detailed study of the efficiency for each extraction is given by the data in Table 10 .

TABLE 10.-Battery extraction of cleaned cottonseed-hull bran: 2,000 $\mathrm{g}$ bran hydrolyzed with 6 liters of $0.16 \mathrm{~N}_{2} \mathrm{SO}_{4}$ extract, for two hours at 10 pounds steam pressure

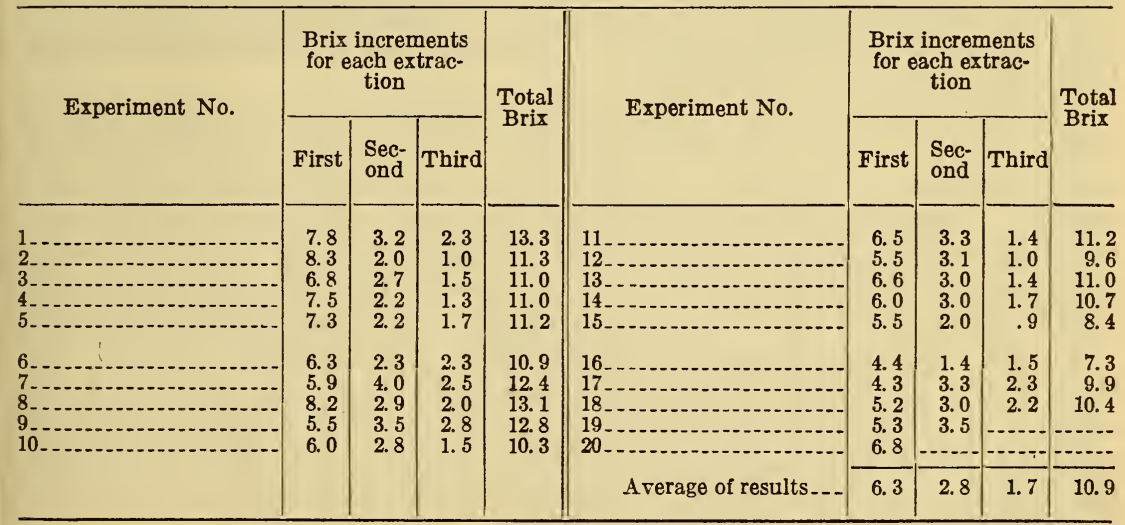

In each case acid-cleaned bran was used and a Brix reading made upon a portion of the drained hydrolysate before and after the cook. A titration and acid adjustment of the hydrolyzing solution was made so that successive cooks were always approximately $0.16 \mathrm{~N}$ mineral acid. The end points in the titration were determined by the use of 
thymol blue indicator in the acid region and interfering colors present in the solutions were compensated for by comparison. The difference between the initial and final Brix readings gave the Brix increments. Just whether the second and third extractions would be profitable commercially as against a single extraction is a question, since over 57 per cent of the sugar available by this procedure was produced in the first cook. The figures also indicate that different batches of bran vary somewhat in their composition; for example, starting with experiment No. 10, Table 10, the bran came from another State.

The isolation of crystalline xylose, after the usual neutralization, evaporation, etc., from the battery extracts, was at first very difficult. Only in one or two cases was there any success, and then only when large volumes of alcohol were employed to precipitate interfering materials. It was concluded that in the pressure cooks, even with such a weak acid, gums and other interfering organic materials were being freed from the bran, and it was their presence that was causing difficulties. Sherrard and Blanco ${ }^{21}$ reported a similar difficulty in their experiments upon a pressure hydrolysis of bagasse and cottonseed hulls. La Forge ${ }^{22}$ in his work on corncobs showed that when a pressure cook was used on corncobs an excellent gum adhesive was produced.

As had been pointed out by Hudson and Harding ${ }^{23}$ and by Markley, ${ }^{24}$ a pretreatment of the bran to remove gums was necessary. Also each of these workers resorted to alcohol for success. Monroe ${ }^{25}$ demonstrated the advantage of giving corncobs a pretreatment with dilute alkali to remove interfering gums in the production of xylose, although it had been prepared from this source without such a treatment.

\section{A MODIFIED PROCESS FOR THE PRODUCTION OF XYLOSE FROM COTTONSEED-HULL BRAN}

Profiting by the experience of others, a modified method was developed to produce xylose whereby interferring gums were removed and crystalline xylose was regularly obtained from the pretreated bran without the aid of alcohol. In this method xylose crystallization took place from water solutions.

The commercial bran, $2,000 \mathrm{~g}$, was covered in a 12-liter jar or flask with 9 liters of water and heated for two hours at 20 pounds steam pressure to remove soluble gums and other interfering substances. In cases where less pressure was used, difficulty was encountered in the crystallization of xylose. Apparently the steam pressure treatment at 20 pounds removed those interfering materials which the acid hydrolysis at 10 pounds steam pressure would have yielded later on.

To get the center portion of the charge at a temperature equal to that of the outer portion required considerable time, since the bran seemed to have excellent insulating qualities. Where one is equipped with an autoclave, having circulating pumps or a stirring device, the length of time necessary for pressure cooks may, in all probability, be diminished by one half.

This first treatment gave an extract containing very little furfural or furfural-yielding material. The solution contained most of the

21 See footnote 17, p. 337

22 J. Ind. Eng. Chem., 16, p. 130; 1924.

23 See footnote 16, p. 337 .
24 See footnote 3 to Table 1, p. 337.

${ }_{25} \mathrm{~J}$. Am. Chem. Soc., 41, p. 1002; 1919. 
uncombined soluble ash in the bran in conjunction with the gums, and it was saved for future studies on gums.

The bran was next drained thoroughly, washed and drained, then given an overnight treatment with 5 liters of cold $0.12 N$ sulphuric acid to dissolve the combined ash. When $2,000 \mathrm{~g}$ of the bran was drained it retained approximately 3 liters of water or extract, and in making up to volumes and calculating concentrations and yields, this fact was always taken into account.

After this treatment to liberate the bound ash the bran was drained thoroughly, washed and drained. Sufficient dilute sulphuric acid and water were added to make a volume of 6 liters of $0.16 \mathrm{~N}$ sulphuric acid, sufficient to cover the bran. The charge was then cooked two hours at 10 pounds steam pressure. The extracts were drained from the bran, cooled, and a Brix reading made. These Brix readings averaged 7.5. A second extraction of this bran with dilute sugar extracts (wash waters) at a concentration of $0.16 \mathrm{~N}$ acid, as in a battery process, gave very low Brix increments. But if fresh $0.16 \mathrm{~N}$ acid was used upon such bran that had been washed free from the absorbed hydrolysate, appreciable amounts of xylose were obtained in the second extraction. However, when sugar extracts were added to fresh precleaned bran and the whole made up to $0.16 \mathrm{~N}$ sulphuric acid and this procedure repeated, each time on fresh bran, concentrated sugar solutions were built up. To cite one case, by carefully manipulating: wash liquors as in a battery process, an extract having a Brix of 17.2 was obtained when four $2,000 \mathrm{~g}$ batches of precleaned bran were successively hydrolyzed. The increments in Brix readings were 7.5 , $5.0,4.5$, and 4.5 .

The hydrolysate contained sugar, xylans, furfural, mineral acid, organic acids, and considerable colloidal and coloring materials. To clarify the extract and further hydrolyze the xylans, 2 per cent by weight of decolorizing carbon was added and the whole cooked one hour at 10 pound steam pressure. If the extract was filtered hot, on subsequent cooling a turbidity appeared. This, however, did not interfere, and when removed later, by filtration, a clear strawcolored sirup was obtained. The presence of furfural and volatile organic acids in the dilute acid sirup gave trouble in the next steps, therefore they were partially removed when the solution was evaporated in vacuo to one-half of its original volume. Even though this evaporation increased the acidity of the solution to $0.32 \mathrm{~N}$, practically, there was no furfural produced, while the bothersome compounds were steam distilled. Also, there was the added advantage in having smaller volumes and lesser amounts of dissolved products of neutralization when the cold hydrolysate was neutralized with powdered calcium carbonate to $\mathrm{pH} 3.0$.

In order to ascertain the effect of hydrogen ion concentration on the amount of calcium going into solution during the neutralization of sulphuric acid in the sugar hydrolysates the following experiment was carried out. To several $25 \mathrm{ml}$ portions of the warm decolorized sugar extract containing $0.14 N$ sulphuric acid ${ }^{26}$ calcium carbonate was slowly added until the approximate $\mathrm{pH}$ values were reachéd. The solutions were allowed to stand over night and the following morning coiorimetric pH determinations were carefully made. They were then filtered and the insoluble residues washed, ignited, treated

\footnotetext{
${ }_{26}$ Extract titrated to first color change of thymol blus indicator for sulphuric acid present.
} 
with sulphuric acid, and again ignited. To the filtrates, oxalic acid was added to precipitate the calcium completely. The calcium oxalate was filtered, washed, and ignited. The results were calculated as calcium sulphate. They were plotted in the graph against the $\mathrm{pH}$ values. The marked increase of calcium going into solution above $\mathrm{pH}$ 3.0, as shown by Curve I (fig. 1), is indicative of the organic acids present. The gradual increase of calcium as shown by Curve II is to be expected, since with increasing $\mathrm{pH}$ values greater amcunts of insoluble calcium carbonate had to be added to obtain these $\mathrm{pH}$ values.

That all the nonvolatile mineral acids present were completely neutralized between $\mathrm{pH} 2.8$ to 3.0 was proved by the fact that evaporations of sugar extracts so neutralized failed to increase in acidity. Because calcium sulphate and calcium bicarbonate are somewhat soluble and thereby cause the sugar sirup to have a high

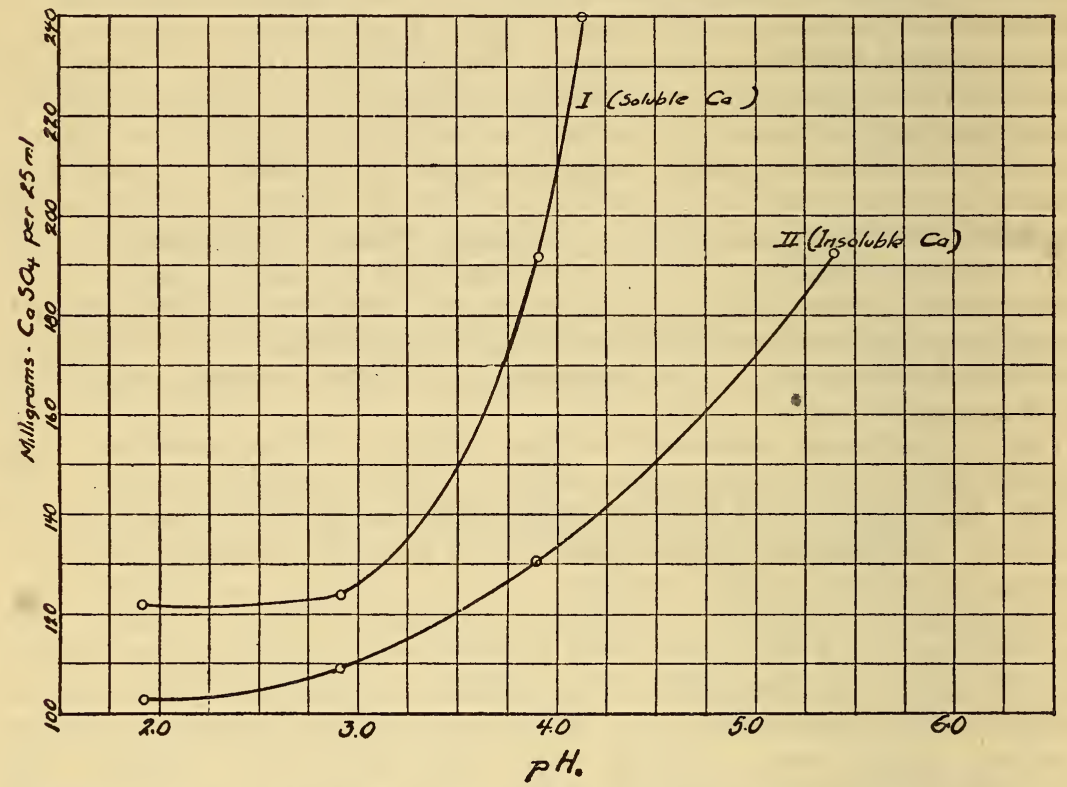

FIGURE 1.-Neutralization of acid in sugar hydrolysates with calcium carbonate

ash content, barium carbonate was substituted for calcium carbonate and later a $40^{\circ} \mathrm{C}$. saturated solution of barium hydroxide was employed. The approximate amount needed for neutralization was determined by a titration with standard alkali to the first color change of thymol blue indicator. Apparently with careful addition and vigorous stirring, little or none of the xylose was decomposed in the neutralization of the hydrolysates. The use of barium hydroxide gave a solution having a low ash value and eliminated bothersome frothing, while the only difficulty encountered was filtering. Decantation of the settled solution was found to be the simplest procedure.

The presence of traces of furfural caused the sirup to become colored at this step, but the color was easily removed by a cold filtration through a bed of carbon.

The almost water-white sirup was finally evaporated in vacuo to a thick sirup having a specific gravity $=1.35$ at $40^{\circ} \mathrm{C}$. It had an 
amber color and readily crystallized in a beaker almost to a solid mass on standing over night. With the aid of a press the mother liquor was removed and the xylose was dried between filter paper. A 9 per cent yield on the basis of the original weight of the bran was obtained. This product was colored light brown and contained 2 per cent ash. Neutralizations with calcium carbonate gave sugar having 3 to 4.5 per cent ash.

In the purification of xylose by recrystallization nearly 30 per cent of the crude product remained in solution, but since the mother liquors were worked over again the loss was recovered. Three methods of purification were used. One was by recrystallization from water; that is, dissolving the sugar in water at $30^{\circ} \mathrm{C}$., decolorizing with carbon (about 1 per cent of the weight of the solution), and evaporating the filtered solution in vacuo on a steam bath to a specific gravity of 1.3 , whereby beautiful needlelike crystals were obtained on allowing the sirup to cool slowly. Perhaps an easier method was to make a 60 per cent solution of xylose in water; namely, to heat the water to boiling, add xylose and warm cautiously, decolorize the hot solution with a 1 per cent carbon treatment, and filter quickly. An equal volume of 95 per cent ethyl alcohol was added to this hot solution. In the case of impure products a precipitate was produced and removed immediately by filtration. The solution was set aside in an ice box to crystallize. The alcohol method gave sugar with only a small trace of ash. The third method, namely, crystallization from water solution in the presence of acetic acid recommended by Monroe, ${ }^{27}$ gave a good product.

Those phases of the procedure described, wherein only water was needed for removal of gums and in the crystallization and recrystallization of xylose, are responsible for success of the investigation.

The principles of the process are now being employed on a semicommercial scale. A cooperative arrangement is now in effect between the National Bureau of Standards, the State of Alabama through her two educational institutions, the University of Alabama and the Alabama Polytechnic Institute, and the Federal Phosphorus Co., of Alabama, in whose plant xylose is being made. It is the aim of this undertaking to produce xylose in 100-pound-per-day quantities.

\section{SUMMARY}

In this paper there is presented some of the representative data on the composition of peanut hulls and cottonseed-hull bran. Experimental data show that the ash content of these plant materials is of a threefold nature. (1) The ordinary dirt and dust held mechanically upon the plant surfaces, (2) ash that is loosely bound chemically, and (3) that ash material which is intimately combined in the organic structure of the plants.

Cottonseed-hull bran is an excellent source for xylose, and peanut hulls and cottonseed-hull bran are rich in furfural-yielding materials.

An improved method, with commercial possibilities for the production of a pentose sugar, xylose, is described.

Washington, September 21, 1929.

37 See footnote 25, p. 340 .

$92380^{\circ}-30-2$ 